\title{
Sob a máscara de Dioniso: a recepção de Nietzsche pela poesia de Augusto dos Anjos
}

\author{
Fábio Martinelli Casemiro*
}

Resumo: Este artigo demonstra a recepção do pensamento de Friedrich Nietzsche pela poesia de Augusto dos Anjos (1884 - 1914), poeta brasileiro que, em vida, publica sua única obra intitulada $E u$ (1912). A tragicidade com que o poeta opera, ironicamente, as máscaras que veste e despe ao longo de sua obra (que organicamente funciona como grande peça trágica); a força apolínea com que desenha as imagens que carregam uma musicalidade tão dilaceratória e incandescente (e , por isso , dionisíaca) são estratégias essenciais da poesia angelina que, certamente dialogam com a filosofia poética de Nietzsche. Palavras-Chave: Augusto dos Anjos, Friedrich Nietzsche, recepção, trágico moderno, poesia Moderna, poesia Brasileira.

\footnotetext{
* Pós doutorando em Letras na Universidade Federal de São Paulo, UNIFESP, Guarulhos, SP, Brasil. ORCID https://orcid.org/0000-0003-2807-4717

Correio eletrônico: fabiomcasemiro@yahoo.com.br
} 
Casemiro, F. M.

\section{Um encontro inusitado?}

Eis um dos poemas menos conhecidos de Augusto dos Anjos, publicado no jornal $O$ Comércio, em 19 de maio de 1905.

Soneto

(A Frederico Nietzsche)

Para que nesta vida o espírito esfalfaste

Em vãs meditações, homem meditabundo?!

- Escalpelaste todo o cadáver do mundo

$\mathrm{E}$, por fim, nada achaste... e, por fim, nada achaste!...

A loucura destruiu tudo o que arquitetaste

E a Alemanha tremeu ao teu gemido fundo!...

De que te serviu, pois, estudares profundo,

O homem e a lesma e a rocha e a pedra e o carvalho e a haste?

Pois, para penetrar o mistério das lousas,

Foi-te mister sondar a substância das cousas

- Construíste de ilusões um mundo diferente,

Desconheceste Deus no vidro do astrolábio

E quando a Ciência vã te proclamava sábio,

A tua construção quebrou-se de repente! ${ }^{1}$

Em 1905, Augusto dos Anjos era estudante da faculdade de Direito, da conhecida Escola do Recife. O poema acima intitula-se apenas "Soneto" e, nele, vemos um comentário sobre a vida e a obra do filósofo Friedrich Nietzsche. Esse poema não pertence a seu único livro publicado em vida, o $E u$ (de 1912), aparecendo somente em edições póstumas que reúnem demais poemas esparsos (há quase um século as editoras optam por publicar a obra que se convencionou denominar Eu e Outras poesias). Observemos o poema mais de perto: trata-se de um poema-obituário. Nele, o poeta homenageia o filósofo

1 Augusto dos Anjos, 2006, p.274. Neste trabalho, todos os poemas aqui citados de Augusto dos Anjos são extraídos desta edição, da Editora Bertrand Brasil, 2006. Julgo ser essa edição a mais bem cuidada, no que diz respeito à fixação dos poemas de Augusto dos Anjos. As demais referências serão, neste caso, grafadas: "ANJOS, p.".

216 | Cad. Nietzsche, Guarulhos/Porto Seguro, v.40, n.3, p. 215-239, setembro/dezembro, 2019. 
alemão, mas de modo crítico, questionando sua vida dedicada à reflexão: trazendo à luz a loucura que acometeu o filósofo em seus derradeiros anos e que, segundo o poema, fez ruir toda sua construção intelectual. Notemos, entretanto, como Augusto descreve o lavor do filósofo: o pensamento nietzschiano "escalpelaria todo o cadáver do mundo", por meio de intensa investigação que percorre macros e microcosmos; vai do homem à lesma, da rocha à pedra, do carvalho à haste. Dessa maneira, o pensamento de Nietzsche sondaria a substância das coisas, penetrando o mistério da morte e, assim, criando (como quem toma consciência) um mundo diferente.

Para Augusto, Nietzsche seria uma espécie de novo Prometeu, que roubaria o fogo divino da razão para iluminar os mistérios do ínfimo. Vencido pelo destino, vitimado pela loucura (abandonado por Deus e pela Ciência), o preço de sua epopeia investigativa não se restringiria simplesmente à morte, mas se estenderia ao ruir de todo o seu edifício intelectual... Mais pesada do que a morte é a vã busca pela visão, é a cegueira de Édipo às portas de Colono.

Meses após ter publicado, no jornal paraibano $O$ Comércio, o soneto dedicado a Nietzsche, Augusto publica este outro soneto, denominado "O ébrio":

O ébrio

Bebi! Mas sei porque bebi!... Buscava

Em verdes nuanças de miragens, ver

Se nesta ânsia suprema de beber,

Achava a Glória que ninguém achava!

E todo o dia então eu me embriagava

- Novo Sileno, - em busca de ascender

A essa Babel fictícia do Prazer

Que procuravam e que eu procurava.

Trás de mim, na atra estrada que trilhei,

Quantos também, quantos também deixei,

Mas eu não contarei nunca a ninguém. 
A ninguém nunca eu contarei a história

Dos que, como eu, foram buscar a Glória

E que, como eu, irão morrer também. ${ }^{2}$

Sileno, sabemos, é o sátiro que cria, que educa o deus Dioniso, e que apresenta a ele o culto da vinha. ${ }^{3}$ A postura do poeta é bem coerente com a do sátiro: idoso e sábio, Sileno é conhecido por se recusar a compartilhar seus conhecimentos. A fim de obtê-los, o rei Midas o aprisiona e recebe dele uma dolorosa resposta, como nos conta Nietzsche em importante passagem de $O$ nascimento da tragédia: helenismo e pessimismo: "- Estirpe miserável e efêmera, filhos do acaso e do tormento! Por que me obrigas a dizer-te o que seria para ti mais salutar não ouvir? O melhor de tudo é para ti inteiramente inatingível: não ter nascido, não ser, nada ser. Depois disso, porém, o melhor para ti é logo morrer." (GT/NT 3, KSA 1.34) ${ }^{4}$

Esses dois poemas (ainda que ambos não tenham sido reunidos em obra pelo poeta) servem como interessante portal de entrada à poesia de $E u$. Conhecedor de episódios da mitologia grega, atento aos debates acerca das correntes filosóficas e poéticas que se vinculam ao trágico moderno, nos deparamos, nessa obra, com um eu lírico que se decompõe em diferentes vozes justamente para fazer da decomposição um canto que mergulha na morte para afirmar sua potência criadora, sua potência de vida. A postura deste eu lírico é sempre uma postura dilacerante: alimenta-se de muitas influências culturais de seu tempo sem, contudo, endossar nenhuma. Ao contrário, estabelece uma contrapoesia $a^{5}$ que tudo devora (à luz do contexto poético brasileiro da época, funciona como constante paródia), sempre se alimentando do contraditório, construindo seu canto num eterno jogo de contrastes.

2 Anjos, 2006, p. 274.

3 Mário da Gama Kury, 2003, p. 357.

4 Todas as citações das obras de Nietzsche são retiradas das publicações da Companhia das Letras, conforme constam nas referências bibliográficas.

5 Fabiano Calixto, 2012, p. 51.

218 | Cad. Nietzsche, Guarulhos/Porto Seguro, v.40, n.3, p. 215-239, setembro/dezembro, 2019. 
Sob a máscara de Dioniso: a recepção de Nietzsche...

\section{A dança de Apolo e Dioniso nos versos na tragédia do $E u$}

Atentemo-nos um pouco sobre a história da obra $E u$ - única obra de Augusto dos Anjos publicada em vida: $E u$ é uma coletânea poética composta de 58 poemas, muitos deles seguem a forma de sonetos, quase todos sob a forma decassilábica. A obra foi publicada em 1912, no Rio de Janeiro. Na obra, vemos emergir diferentes vozes que falam pela voz do eu lírico, sempre apontando para a decomposição do próprio eu e do mundo que ele vivencia. É de dentro desse eu em decomposição, que o eu lírico se apresenta ora como eu sombra, ora como eu sátiro, ora como eu doente, ora como eu filósofo moderno - para ficarmos em algumas das muitas máscaras que o eu lírico veste e despe-se. É a partir dessa multiplicidade de máscaras que o eu lírico narra a decomposição do mundo, conferindo a essa poesia uma tonalidade alucinatória, como num delirium tremens.

Se, por um lado, a obra $E u$ se assemelha a uma simples coletânea de poemas líricos, por outro, é possível encontrar uma unidade que perpassa os poemas e que aponta para uma consistente e orgânica trama dramática: há um percurso, um verdadeiro caminho, que o eu lírico percorre, como um Dante em vertiginosa descida pelos círculos infernais. ${ }^{6}$ Entretanto, em $E u$ não há a figura de um poeta-guia (como ocorre com Virgílio guiando Dante n’ A divina comédia); ali são os vermes, os cachorros que uivam nos bosques, as diatomáceas da lagoa, os bêbados, os negros, os miseráveis, as prostitutas e todos os seres do ínfimo que podem cantar pelo "mulambo da língua paralítica" desse poeta, uma espécie de Cristo-Augusto em constante decomposição. Se em comum com a obra do poeta italiano há esse périplo, na obra de Augusto, diferentemente, constatamos um processo mais dinâmico: as situações nas quais Dante percorre as terras de Malebolge são externas ao corpo do poeta-narrador que

6 Antonio Arnoni Prado, 2004, pp. 183-196.

Cad. Nietzsche, Guarulhos/Porto Seguro, v.40, n.3, p. 215-239, setembro/dezembro, 2019. $\mid 219$ 
se aventura. Em $E u$, notemos, essa descida é a um só tempo interna e externa ao corpo do poeta: sendo mais específico, ela se centra no crânio do eu lírico, (aparecendo representada em sua facialidade) e que vivencia seu inferno pelas múltiplas máscaras (são personas trágicas) as quais veste e despe, (con)fundindo os limites entre o eu e o mundo, ambos em decomposição. $\mathrm{O}$ inferno angelino mostra-se, assim, como um inferno ao mesmo tempo pessoal e universal.

Olhemos Eu mais de perto: notemos que a obra se inicia com um monólogo, o "Monólogo de uma sombra". Tradicionalmente, no universo da tragédia, o monólogo é, ele mesmo, uma peça dramática, ou ainda um trecho de uma obra dramática; em $E u$, ele funciona como apresentação da condição do "eu herói” diante das forças telúricas, ou seja, diante da voz da natureza que se impõe ao poeta (e aos demais leitores/espectadores) como força suprema a subjugar o "protagonista" - o próprio eu lírico. Dessa forma, ele ali nos prepara para a sucessão de transfigurações que irá sofrer (pelas personas que veste e despe, sempre ditirâmbico, ora sob a máscara do verme, ora sob a máscara do filósofo-moderno, ora sob a máscara do doente), diante de seu destino: será dilacerado, decomposto, aniquilado.

Observemos o início de "Monólogo de uma sombra":

Monólogo de uma sombra

"Sou uma Sombra! Venho de outras eras,

Do cosmopolitismo das moneras...

Pólipo de recônditas reentrâncias,

Larva de caos telúrico, procedo

Da escuridão do cósmico segredo,

Da substância de todas as substâncias!?

Nessa primeira estrofe, reconhecemos uma das personagens que falam pela voz do eu lírico, a "sombra", que é a "canção da

7 Anjos, 2006, p. 91.

220 | Cad. Nietzsche, Guarulhos/Porto Seguro, v.40, n.3, p. 215-239, setembro/dezembro, 2019. 
Natureza exausta"8 sob a persona de sua "vida anônima de larva". É a voz terrível do desdém da natureza diante da efemeridade da vida do homem, e que ouvimos rogar praga à personagem do "filósofo moderno":

$[\ldots]$

E hão de achá-lo, amanhã, bestas agrestes, Sobre a esteira sarcófaga das pestes A mostrar, já nos últimos momentos, Como quem se submete a uma charqueada, Ao clarão tropical da luz danada,

O espólio dos seus dedos peçonhentos.

$[\ldots]^{10}$

Notemos, contudo, que o poema se inicia com a voz da sombra, abrindo-se ali o sinal de aspas que somente será fechado na $28^{\mathrm{a}}$ estofe, quando a voz do eu lírico assumirá o poema, mas agora despido de sua persona: resta a ele apenas mais três estrofes. A forma monológica que hegemonicamente o poema assume aponta para a constatação de uma dimensão dramática, o que se confirma pela ação no tempo presente (em que a peça/poema é encenada/lida): notemos o uso dos verbos no presente ("Sou uma sombra"; "Pairando acima"; "Aí vem sujo"). Essa confirmação se dá também no momento em que aparece outra personagem comum à obra, o sátiro: ali o verbo no presente ("é"), combinado ao dêitico ("agora"), traz a realização da ação para o momento presente:

Estoutro agora é o sátiro peralta

Que o sensualismo sodomista exalta,

Nutrindo sua infâmia a leite e a trigo...

Como que, em suas células vilíssimas,

8 Anjos, 2006, p. 96.

9 Anjos, 2006, p. 96.

10 Anjos, 2006, p. 92.

Cad. Nietzsche, Guarulhos/Porto Seguro, v.40, n.3, p. 215-239, setembro/dezembro, 2019. | 221 
Há estratificações requintadíssimas

De uma animalidade sem castigo. ${ }^{11}$

Como mostra Anatol Rosenfeld, em Teatro épico: "A ação dramática acontece agora e não aconteceu no passado [...] Origina-se, cada vez, em cada representação, "pela primeira vez"; não acontece "novamente" o que já aconteceu, mas, o que acontece, acontece agora, tem sua origem agora; a ação é "original", cada réplica nasce agora, não é citação ou variação de algo dito há muito tempo."13

A força dramática anunciada nesse poema de abertura funciona como uma chave que permite adentrar pela porta dessa poesia. É óbvio que nem o poema de abertura, nem tampouco toda a obra $E u$ se configuram, a rigor, como ato e obra dramáticos, respectivamente, no entanto, como mostra Lucia Helena em A cosmo-agonia de Augusto dos Anjos" : a "trama dramática" tão característica de Eu articula os poemas tragicamente, fundindo-se ao "traçado épico" da obra, ou seja, à narrativa que mostra a decomposição do $E u$ em sua deambulante aventura pelos umbrais da decomposição. ${ }^{15}$

Observemos que essas "ações dramáticas", embora predominantemente reflexivas, estão circunscritas à própria experiência do eu lírico, de seu sofrimento, ou seja, elas são experimentadas pelo eu lírico que já não é mais somente uno e que se torna, pela decomposição, um corpo múltiplo (é “o mulambo da língua paralítica", ou ainda "a fauna cavernícola do crânio", ou ainda o "verme", ou o "filósofo moderno" que participam da

11 Anjos, 2006, p. 93.

12 Anatol Rosenfeld, 2008.

13 Anatol Rosenfeld, 2008, p. 31, grifos do autor.

14. Lucia Helena, 1977.

15 Para Lucia Helena, o périplo por meio da decomposição que o eu lírico realiza, partindo do primeiro poema e indo até o último (daí o "traçado épico"), inscreve na obra $E u$ um ciclo constante de destruição (devoramento, ou ainda "fagismo") e de subsequente recriação da vida. Daí o título de sua obra A cosmo-agonia de Augusto dos Anjos.

222 | Cad. Nietzsche, Guarulhos/Porto Seguro, v.40, n.3, p. 215-239, setembro/dezembro, 2019. 
Sob a máscara de Dioniso: a recepção de Nietzsche...

ação). Assim esse eu da obra apresenta-se, simultaneamente, como protagonista, antagonista e palco da ação dramática: os demais seres que participam dessa "trágica festa emocionante" são incorporados pelo eu lírico, que se veste e se despe dionisiacamente de suas personas, como numa decomposição do próprio eu-a(u)tor. Assim, o tom que predomina na obra $E u$ é o do monólogo, no qual a voz lírica se traveste de outras personagens, mas todas numa dança em cuja música reverbera a decomposição, epicentro temático de $E u$. Sendo que essa poesia parte da experiência do eu lírico em sua própria carne, da vivência de seu próprio corpo decomposto, ela se alinha bastante ao antiplatonismo pós-kantiano de Arthur Schopenhauer e de Friedrich Nietzsche.

Esse caminho do herói trágico-moderno (nesse grande monólogo/ canto ditirâmbico que é $E u$ ) é a busca do conhecimento (na persona do filósofo moderno) e de sua salvação (sua harmatia é a crença na ciência) até que, finalmente, encontre seu destino trágico, sua decomposição no último poema: "Mistérios de um fósforo", que funciona na obra como uma espécie de réquiem.

Se a obra Eu não é formalmente uma tragédia, por outro lado, a obra dialoga, joga, com elementos próprios do gênero "drama trágico" (em muitos momentos cita e anuncia as dores decompositórias como "trágicas") e, assim, constrói uma obra em que a energia trágica é sua grande força motriz. A poesia de $E u$ é a poesia trágica (uma "tragédia moderna") na qual o eu lírico se despe - como quem se decompõe de suas personas até ser desmembrado, sacrificado, juntamente com o ideal de progresso da civilização e com a civilização ela mesma, para que, desse processo de decomposição, emerja a poesia. A poesia de Augusto dos Anjos usa a ciência para a criação poética, transformando-a em poesia, para criar um canto de decomposição em que se desmembram o próprio eu lírico e essa ciência que o alimenta. 
Por meio da lógica da queda de máscaras "em sucessão indefinida" ${ }^{16}$, podemos compreender como a presença do nosológico e do biográfico na obra revelam-se poderosas estratégias poéticoretóricas do eu lírico: eis a armadilha na qual sucumbe grande parte da crítica que se dedica à obra. $\mathrm{O}$ que está em jogo nesta poesia é a própria criação poética: esse eu lírico se oferece em holocausto (é o filósofo moderno, a decadência do engenho em si mesmo, a promiscuidade da cidade e da República, a decrepitude da civilização e de sua fé na ciência) em nome da poesia, de sua própria poesia. Esse canto mostra-se, assim, um canto de vida, porque é o canto da criação poética; ao contrário do que pregavam alguns críticos do passado (e alguns ainda teimosamente hoje), Augusto dos Anjos não é o "poeta da morte", mas sim, o poeta da decomposição e, sendo a decomposição o primeiro passo para uma nova composição (como o eu lírico anuncia no poema "Os doentes"), ele é o poeta da recriação poética e, com ela, da recriação da vida.

Se essa poesia canta a criação pela decomposição (a destruição, a morte), então temos aqui um jogo de polaridades, de princípios (eros e tanathos) que não se resolvem, não se neutralizam, mas que se casam. Sob essa mesma lógica paradoxal, de polaridades que se "casam" e, contudo, não se neutralizam, encontraremos a dança de Apolo e Dioniso na poesia angelina: Apolo como divindade da bela forma, da imagem, o olho solar que revela o prazer da aparência (shein, como nos mostra Nietzsche em $O$ Nascimento da tragédia...), e Dioniso, como a divindade da destruição, mostra-se como princípio da música, do êxtase e do terror diante da dissolução do eu (o principium individuationis) no Uno-primordial.

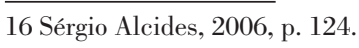

224 | Cad. Nietzsche, Guarulhos/Porto Seguro, v.40, n.3, p. 215-239, setembro/dezembro, 2019. 
Sob a máscara de Dioniso: a recepção de Nietzsche...

\section{Por um pessimismo da vida: Augusto, de Schopenhauer à Nietzsche}

Em muitos dos textos da fortuna crítica de $E u$ nos deparamos com a concepção do trágico atrelado à filosofia pessimista de Schopenhauer: "Certo, no pessimismo está a verdade verdadeira, a verdade inclemente. Mas só um espírito criado no leito do budismo e alimentado pelo schopenhauerianismo seria capaz de soltar grito tão desesperativo"17. Entretanto, a poesia de $E u$ não pode ser resumida à simples condição de texto de divulgação desta ou daquela corrente filosófica. Ao lermos a obra Eu na chave do trágico, faz-se mister compreendermos que as filosofias do trágico de ambos os pensadores alemães (Schopenhauer e Nietzsche) não se opõem, simples e diretamente. Então, compreender em que medida a poesia trágica de $E u$ se aproxima e se afasta de uma ou de outra abordagem é compreender com mais clareza as especificidades - e a beleza, creio - de seu corpo poético. Acredito que a poesia de Augusto dos Anjos parte do corpo fenomênico de Schopenhauer e desagua no corpo dionisíaco de Nietzsche. Observemos mais de perto o significado de "trágico" para ambos os filósofos.

Schopenhauer é, nas palavras do jovem Nietzsche, ${ }^{18}$ o grande "educador": sobre os fundamentos de Schopenhauer se assentam as ideias de Nietzsche, e, ainda depois de romper com o mestre, Nietzsche irá manter determinados pressupostos schopenhauerianos. Nietzsche parte dos preceitos de "vontade e representação" de Schopenhauer, mas, no filósofo de Sils-Maria, eles estão transfigurados nos princípios "dionisíaco" e “apolíneo”, respectivamente. Para

17 O. Soares, 2006, p. 67.

18 A partir dos estudos de Oswaldo Giacóia sobre Nietzsche, compreendemos três distintos momentos da produção nietzschiana: o "jovem Nietzsche" (de 1870 a 1876, cuja principal obra é $O$ nascimento da tragédia a partir do espírito da música); o "segundo Nietzsche" (de 1876 a 1882, período no qual encontramos Humano, demasiado Humano: um livro para espíritos livres); e o "último Nietzsche" (de 1882 a 1889, quando da publicação de Assim falou Zaratustra: um livro para todos e para ninguém). Cf., Oswaldo Giacóia Júnior, 2000.

Cad. Nietzsche, Guarulhos/Porto Seguro, v.40, n.3, p. 215-239, setembro/dezembro, 2019. | 225 
ambos, a arte manifesta o jogo entre a vontade (em Nietzsche, o princípio dionisíaco) e a representação (em Nietzsche, o apolíneo). A cisão entre Nietzsche e Schopenhauer virá das consequências dessa premissa.

Não seria exagero pensarmos que o que Nietzsche realiza com sua obra é a radicalização do pensamento schopenhaueriano (para além do que almejava o próprio Schopenhauer). Para Nietzsche a tragédia é também a grande expressão artística por excelência, mas, onde Schopenhauer vê negação da vontade, Nietzsche vê afirmação da vontade, afirmação da vida. Para Nietzsche, o resultado da tragédia - que é o expectador extasiado diante da destruição do herói não imprime a negação da vontade, mas, ao contrário, afirma a vontade porque faz o espectador aceitar o sofrimento com alegria, com entusiasmo (dionisíaco); segundo Machado, o espectador passa a aceitar o sofrimento "como parte integrante da vida, porque seu próprio aniquilamento como indivíduo em nada afeta a essência da vida, o mais íntimo do mundo, da vontade". ${ }^{19}$ A visão nietzschiana parte de um episódio pouco elucidado na filosofia de Schopenhauer: se a arte possibilitaria a anulação da vontade, a música - sendo manifestação artística - também deveria provocar no espectador a mesma atitude. Entretanto, quando trata da música (e do efeito que causa no ouvinte, diante das dissonâncias e consonâncias que representam os prazeres e desprazeres da vontade), em nenhum momento ele vincula a música à negação da vontade (e, como vimos, para Schopenhauer, a negação da vontade é a finalidade da arte). Eis que nesse ponto cego da teoria de Schopenhauer sobre o trágico é que encontramos o alicerce do pensamento de Nietzsche, que em 1872, publica sua obra $O$ nascimento da tragédia e o espírito da música. Segundo Roberto Machado:

19 Roberto Machado, 2006, p. 238.

226 | Cad. Nietzsche, Guarulhos/Porto Seguro, v.40, n.3, p. 215-239, setembro/dezembro, 2019. 
Aliás, Jean-Marie Schaeffer argumenta, a esse respeito, que, se a música é a expressão direta da vontade e se ela sempre termina com uma consonância, portanto com a expressão de uma satisfação, então a expressão da essência das coisas não conduz à negação da vontade de viver: leva à indiferença ou, mais provavelmente, a uma afirmação dessa vontade. Interpretação que o leva a considerar a concepção schopenhaueriana da música mais condizente com a filosofia de Nietzsche do que com o pessimismo do próprio Schopenhauer - lembrando que, efetivamente, Nietzsche retomará a concepção schopenhaueriana, tornando-a independente de sua filosofia pessimista, tornando-a o emblema da autoafirmação da vontade de potência. ${ }^{20}$

Da compreensão do mundo como vontade e representação parte o jovem Nietzsche para pensar o trágico, cujo espírito é a música. Sua conhecida postura combativa diante do pensamento de Schopenhauer irá se desenvolver num segundo momento, em que Nietzsche se reaproximará da ciência, desenvolvendo suas investigações acerca da moral e da ética, começando a traçar o que denominou de "método genealógico". Nesse "segundo Nietzsche", por volta do início dos anos 80 do século XIX, veremos a publicação de obras como Aurora (1881) e A gaia ciência (1882).

$\mathrm{O}$ trágico sempre se mostrará ponto fundamental à filosofia nietzschiana: anos mais tarde, no intuito de rearticular o conhecimento de seu primeiro livro, ${ }^{21}$ Nietzsche compõe a obra Assim falou Zaratustra: um livro para todos e para ninguém. Para ele, O nascimento da tragédia se mostrou um livro problemático, pois, para além da presença indesejável do "cadavérico aroma de Schopenhauer" (EH/ EH, O nascimento da tragédia, 1, KSA 6.309) (e de Wagner), a obra se mostraria, estética e eticamente, incompatível com sua essência; assim, ao invés de se valer de uma linguagem "sistemática e

20 Roberto Machado, 2006, p. 200.

21 É o que nos aponta Roberto Machado em Zaratustra, tragédia nietzschiana. Cf.: Roberto Machado, 2011.

Cad. Nietzsche, Guarulhos/Porto Seguro, v.40, n.3, p. 215-239, setembro/dezembro, 2019. | 227 
Casemiro, F. M.

conceitual", ${ }^{22}$ Nietzsche - ele mesmo o afirma no prefácio "Tentativa de autocrítica" - deveria tê-la "cantado".

Eis que reconhecemos aqui o ponto de convergência entre os pensamentos de Friedrich Nietzsche e de Augusto dos Anjos: para ambos a poesia trágica é um autêntico lugar de conhecimento; esse conhecimento poético é filosófico e vice-versa (em ambos, notemos, o conhecimento poético supera aquilo que, nos versos de Augusto, poderíamos denominar "os métodos da abstrusa ciência fria").

É interessante que, também para ambos, o termo evangelho seja uma inspiração: se para $E u$ a podridão serve de evangelho ao eu lírico (em "Monólogo de uma sombra" encontramos: "A podridão me serve de evangelho..."23), para Nietzsche, evangelho é a obra Assim falou Zaratustra: um livro para todos e para ninguém. À medida que o filósofo alemão amadurece sua filosofia trágica, ele compreende que o conhecimento científico, ao invés de ser simplesmente recusado, deve ser incorporado pela criação de um novo conhecimento que tenha na criação poética sua força motriz. Daí que grande parte da obra $A$ gaia ciência (obra de transição do $2^{\circ}$ ao último Nietzsche) é escrita sob a forma de poemas líricos.

Assim, o Eu de Augusto dos Anjos é o poema trágico que narra a decomposição do herói que é, ele mesmo, o principium individuationis. Esse $E u$, decompondo-se, ruma para o "nada panteístico" que é conceito importante tanto para Schopenhauer quanto para Nietzsche. A proximidade com a filosofia nietzschiana se mostra mais intensa, se nos atentarmos para o modo como a dissonância musical dos versos de $E u$ se configuram a partir do jogo entre os princípios nietzschianos apolíneo e dionisíaco e que imprimem musicalidade à dramaticidade da poesia lírica é essa peculiar musicalidade da

22 Roberto Machado, 2011, p. 17.

23 Augusto dos Anjos, 2006, p. 91. A expressão "Evangelho da podridão" já se tornou uma perífrase da obra $E u$. Uma das mais célebres utilizações da expressão está no título da tese de Chico Viana: O evangelho da podridão: culpa e melancolia em Augusto dos Anjos. Cf. Chico Viana. 2012.

228 | Cad. Nietzsche, Guarulhos/Porto Seguro, v.40, n.3, p. 215-239, setembro/dezembro, 2019. 
poesia de Augusto dos Anjos que permitiu - inadequadamente, a meu ver - que muitos críticos relacionassem sua poesia à estética do simbolismo brasileiro. Há, na poesia angelina, uma musicalidade muito peculiar, esdrúxula, "mastigatória", próxima das sintaxes quebradas do expressionismo alemão (como nos poemas de Georg Trackl), carregada de uma tonalidade mórbida e dilaceratória (como na obra Morg do poeta Gottfried Benn ${ }^{24}$. Notemos abaixo alguns trechos da poesia de $E u$ :

O Deus-Verme

Almoça a podridão das drupas agras, Janta hidrópicos, rói vísceras magras

$\mathrm{E}$ dos defuntos novos incha a mão... ${ }^{25}$

Monólogo de uma Sombra

Brancas bacantes bêbadas o beijam.

Suas artérias hírcicas latejam,

Sentindo o odor das carnações abstêmias, ${ }^{26}$

As Cismas do Destino

Livres de microscópios e escalpelos,

Dançavam, parodiando saraus cínicos,

Bilhões de centrossomas apolínicos

Na câmara promíscua do vitellus. ${ }^{27}$

O abuso das rimas esdrúxulas (proparoxítonas), somada à sonoridade das consoantes fricativas e das lábio-dentais (muitas vezes acrescidas de labiais como o $m$ e $o p$ ) e aliadas à temática

24. Críticos como Anatol Rosenfeld e Suzana Kampff Lages reconhecem as semelhanças estéticas entre a poesia de Augusto dos Anjos e a poesia do expressionismo alemão, principalmente em se tratando dos versos de Gottfried Benn. Cf. ROSENFELD, Anatol Rosenfeld, 2004, pp. 186 - 190; Cf. LAGES, Suzana Kampff Lages, 2002. pp. 157-188.

25 Anjos, 2006, p.101.

26 Anjos, 2006, p. 94.

27 Anjos, 2006, p. 103.

Cad. Nietzsche, Guarulhos/Porto Seguro, v.40, n.3, p. 215-239, setembro/dezembro, 2019. 
decompositória e irônica que desligam a terminologia científica, geram uma musicalidade mastigatória intensa - é o coro de vermes que tanto testemunham como, por vezes, protagonizam as ações -, muitas vezes aliada às cenas de grande movimento e plasticidade... Tais elementos imbuídos de um sentido geral de decomposição cosmo-agônica, grávido do horror da destruição (o dionisíaco é a face do horror) resultam numa poesia carregada de plasticidade que se expressa na forma equilibrada do decassílabo. As ricas imagens que resultam desse processo vulcânico e que o delimitam: eis a expressão formal que caracteriza o princípio apolíneo, o Shein (GT/NT, 1, KSA 1.25), que nos mostra o pensamento trágico nietzschiano.

Esse conteúdo horroroso cantado por uma musicalidade tão saborosa produz uma poética cuja linguagem e cuja temática se embriagam da realidade desse mundo em decomposição que trata tanto da decadência econômica dos engenhos da família dos Anjos, quanto da opressão política e cultural que os brancos europeus exerceram sobre os negros e sobre os povos ameríndios. O que vemos nessa poesia é o horror diante da decomposição e o êxtase da música - energias dionisíacas - envasados pela bela forma apolínea de seus decassílabos, de seus sonetos, e, principalmente, envasados pelas imagens coloridas, dinâmicas, macro e microscópicas, que tanto caracterizam essa poesia. A musicalidade e a forma poética próprias dos versos de $E u$ reiteram estilisticamente a dimensão crítica que essa poesia trágica assume: uma criticidade diante da civilização, não somente a brasileira, criticidade esta que se expressa pela estratégia trágica de sua (de)composição poética.

Daí podermos afirmar "que a poesia de Augusto dos Anjos parte do corpo fenomênico de Schopenhauer e desagua no corpo dionisíaco de Nietzsche". A experiência de dissolução (decomposição) do próprio eu (principium individuationis), essa "abdicação panteísta da individualidade"28 é um movimento marcadamente schopenhaueriano,

28 José Paulo Paes, 2003 (Melhores Poemas 19), pp. 11-35. p. 25.

230 | Cad. Nietzsche, Guarulhos/Porto Seguro, v.40, n.3, p. 215-239, setembro/dezembro, 2019. 
contudo esse corpo que se decompõe para investigar a decomposição, ele canta, ele afirma a poesia, ironizando seus mestres. É o que vemos nesta estrofe de "As cismas do destino":

\section{Todos os personagens da tragédia, Cansados de viver na paz de Buda, Pareciam pedir com a boca muda A ganglionária célula intermédia. ${ }^{29}$}

Esse eu lírico percorre a decomposição do mundo e de si mesmo, sorrindo ironicamente, como afirma o crítico Fausto Cunha: "Trágico sim, mas de um humor trágico. $O$ poeta não se entrega desarmado à sua tragédia: enfrentara-a sabendo de usa inutilidade de burla". Pode-se dizer que esse sorriso diante da condição trágica que se impõe ao eu lírico é semelhante ao núcleo do trágico nietzschiano.

\section{Incipit tragoédia, incipit parodia}

É vestido de doente que o eu lírico percorre, ébrio de êxtase dionisíaco (seu périplo pelo mundo do ínfimo é sempre alucinatório), a "noite dos vencidos", encontrando, ao amanhecer, a vitória (e com ela a alegria) dos seres inferiores. À medida que percorre, sonambúlico, a noite delirante, reconhece os signos de decomposição e, extasiado pelos cânticos de seu "pseudo-salmo", ruma para a alegria do amanhecer, reconhecendo, sob a luz do sol, uma nova aurora, um novo raiar do dia que não recusa, mas sim que coroa a beleza da revelação pela decomposição, encontrando, sob essa solaridade, a beleza apolínea das imagens decompositórias, afirmando a alegria da vida pela dor da decomposição. Ora vestindo-se de "filósofo moderno", ora de "doente", ora de "sombra" (esta última, representante máxima das forças telúricas, vérmicas, da natureza), ora de ébrio, ora de Augusto (ele mesmo), o poeta brinca com as

29 Anjos, 2006, p. 107.

Cad. Nietzsche, Guarulhos/Porto Seguro, v.40, n.3, p. 215-239, setembro/dezembro, 2019. $\mid 231$ 
tradições que recupera, decompondo tradições ao mesmo tempo em que decompõe a si mesmo. Pela troca de máscaras "em sucessão indefinida", ${ }^{30}$ esse Eu lírico torna-se o próprio deus da máscara: Dioniso, o deus ridente.

Profundamente irônica e, muitas vezes, até paródica é, também, a filosofia de Friedrich Nietzsche. Em 1882 publica $A$ gaia ciência, livro em que se encontra sua já conhecida forma aforismática, mas que também reúne poemas líricos nos quais apresenta seus "ensinamentos"31, sempre ironicamente, como no poema "Vademecum - Vadetecum", em que propõe o livre pensar aos seus "discípulos":

Atraem-no meu jeito e minha língua,

Você me segue, vem atrás de mim?

Siga apenas a si mesmo fielmente:-

Assim me seguirá - com vagar! com vagar!

(FW/GC, Brincadeira, Astúcia e Vingança, 7, KSA 3.354) ${ }^{32}$

\section{Ou ainda, avisando o leitor em "Minhas rosas":}

Sim, minha felicidade quer fazer feliz,

Toda felicidade quer fazer feliz!

Querem vocês colher minhas rosas?

Terão de curvar-se e esconder-se

Entre rochas e espinheiros,

E com frequência lamber os dedinhos!

30 S. Alcides, 2006, p. 124.

31 Segundo Giacóia, A gaia ciência se caracteriza por um "aprofundamento e intensificação das preocupações pedagógicas [...] Para esse leitor ideal, o livro não visa ensinar uma doutrina; sua lição fundamental é a responsabilidade do pensamento independente". $C f$.: Giacóia, 2000, p. 51.

32 Em nota à obra A gaia ciência, Paulo César de Souza mostra a ambiguidade da palavra "Vademecum": além de comumente designar espécie de manual ou guia, o sentido estrito da expressão é "venha comigo". Daí a brincadeira com o sentido da palavra seguinte, "vadetecum", ou seja: "para vir comigo é necessário que vás contigo mesmo", indicando assim a busca pela formação do espírito livre, um dos principais objetivos dessa obra de Nietzsche. Cf.: F. Nietzsche, 2012, p. 318.

232 | Cad. Nietzsche, Guarulhos/Porto Seguro, v.40, n.3, p. 215-239, setembro/dezembro, 2019. 
Sob a máscara de Dioniso: a recepção de Nietzsche...

Pois minha felicidade é traquinas!

Pois minha felicidade é maldosa! -

Querem mesmo colher minhas rosas?

(FW/GC, Brincadeira, Astúcia e Vingança, 9, KSA 3.355)

Ao final do primeiro aforismo do prólogo de A Gaia ciência, encontramos o filósofo anunciando, metalinguisticamente, a correspondência de sentidos no modo como articula os termos "tragédia" e "paródia":

[...] "gaia ciência" - por exemplo, o punhado de canções que agora vêm juntadas a esse livro - canções nas quais um poeta, de maneira dificilmente perdoável, zomba de todos os poetas. - Ah, não é apenas nos poetas e seus belos "sentimentos líricos" que este ressuscitado precisa dar vazão à sua malícia: quem sabe que vítima ele não está procurando, que monstruoso tema de paródia o estimulará em breve? "Incipit tragoedia" [A tragédia começa] - diz o final deste livro perigosamente inofensivo: tenham cautela! Alguma coisa sobremaneira ruim e maldosa se anuncia: incipit parodia, não há dúvida... (FW/GC, Prólogo, 2, KSA 3.347)

Vestindo-se de "ressuscitado" (e começando a travestir-se de Cristo, como o fará posteriormente em Ecce homo), Nietzsche anuncia, já no início desta, sua próxima obra: no livro IV (denominado "Sanctus Januarius") de A gaia ciência, no aforismo de número 342, sob o título de "Incipit tragoedia", o filósofo apresenta a primeira parte do "Prólogo de Zaratustra" - a abertura daquele que é, talvez, o seu mais famoso livro. É em Zaratustra: um livro para todos e para ninguém que essa dimensão parodístico-trágica já anunciada em $A$ gaia ciência se revelará em sua plenitude: segundo Roberto Machado (em seu livro Zaratustra, tragédia nietzschiana), somente em Zaratustra é que Nietzsche consegue finalmente realizar o intuito de seu primeiro livro (O nascimento da tragédia a partir do espírito da música): fundir o fazer filosófico ao artístico e assim chegar ao 
"ápice de sua filosofia trágica". ${ }^{33}$ Nesse primeiro aforismo do prólogo de A gaia ciência (que aqui citamos), já encontramos sistematizada a correspondência entre incipit tragoedia e incipit parodia, que marca o pensamento trágico dionisíaco de Friedrich Nietzsche.

À medida que percorremos as obras de Nietzsche, observamos claramente como seu pensamento trágico se atrela profundamente à figura da divindade grega, clamada constantemente por sua filosofia: ridente é a máscara de Dioniso, o deus da máscara par excellence, o deus da tragédia. Eis a essência do trágico nietzschiano que encontramos na poesia de Augusto dos Anjos: mais do que simplesmente trágica, a obra $E u$ se organiza pelo trágico dionisíaco. É igualmente a Dioniso que o trágico-nietzschiano se reporta ao longo de toda a produção desse filósofo, desde $O$ nascimento da tragédia até Ecce homo, quando, às vésperas do colapso nervoso, o filósofo veste a máscara do deus.

Indubitavelmente, essa é a grande importância do pensamento nietzschiano para a poesia de Augusto dos Anjos: a presença de Dioniso como o ridente deus da máscara, do drama trágico, cuja expressão máxima se dá pela música lírico-trágica. Provavelmente, a poesia de Augusto dos Anjos toma, da filosofia trágica de Nietzsche, a importância da música, o uso das máscaras de Dioniso, mas o faz bastante a seu modo, a fim de construir sua trama trágico-moderna. Contudo, o não alinhamento estrito à filosofia de Nietzsche é mais um indício que aponta para a importância que o trágico nietzschiano assume na poesia de Augusto dos Anjos; como vimos em A gaia ciência: "Vademecum - Vadetecum".

A decomposição do eu (principium individuationis) em múltiplos "eus", em sua já citada queda de máscaras "em sucessão indefinida" apresenta-se como jogo que culmina na revelação da própria máscara de Dioniso, o ridente deus da máscara. Essência da tragédia grega antiga (bem como nas demais comunidades "primitivas" em que

33R Machado, 2011, p. 20.

234 | Cad. Nietzsche, Guarulhos/Porto Seguro, v.40, n.3, p. 215-239, setembro/dezembro, 2019. 
se encontra o uso das máscaras), a máscara simboliza o contato do(a) mascarado(a) com os deuses, com os mortos, com as forças da natureza. Pela máscara o homem se torna mulher (e vice-versa), o mortal se torna o deus (e vice-versa): transfigurando-se pela máscara o "eu" se torna o "outro", ou ainda o "não eu". Esse dionisíaco jogo de máscaras é a chave da estratégia poética do eu "multipersona" que perpassa todos os poemas de $E u$.

\section{Um Anjo na máscara do Anti-Cristo?}

Retomemos aqui o soneto dedicado a Nietzsche, com o qual abrimos esta reflexão. Ainda que não arrolado na obra $E u$, ele se presta a iluminar a paródia de Augusto dos Anjos, rindo de seus mestres. A estrutura do soneto se enquadra bastante nos moldes da poesia da época: é um soneto alexandrino, cuja cesura predominante é na $6^{\mathrm{a}}$ sílaba poética. Considerando-se que o soneto é forma fixa, composta de 14 versos, vemos, no $8^{\circ}$ verso, uma marca diferenciadora: ali encontramos uma exagerada fusão de vogais, resultando numa sonoridade estranha, bastante comum, como já vimos, na poesia de Augusto dos Anjos. Quiçá o eu lírico nos dê uma piscadela: concentrando tão enfaticamente neste verso sua assinatura, ele nos convida a olhá-lo mais de perto:

$$
\begin{array}{cccccccccccc}
1 & 2 & 3 & 4 & 5 & 6 & 7 & 8 & 9 & 10 & 11 & 12 \\
0 & / \mathrm{ho} / \mathrm{mea} / \mathrm{les} / \mathrm{mea} / \mathrm{ro} / \mathrm{chea} / \mathrm{pe} / \mathrm{dreo} / \mathrm{car} / \mathrm{va} / \text { lhas/te }
\end{array}
$$

O verso está no centro do poema, e é nesse centro geográfico que encontraremos o alicerce de sua ironia, pois exalando sua musicalidade idiossincrática - como num chiste $^{34}$ - ele deixa cair sua máscara: o eu lírico executa, neste verso, o mesmo movimento

34 Empresto o termo aqui da psicanálise sem, contudo, adentrar nas muitas possibilidades de análise de poesia que aqui poderíamos executar a partir de pensadores como Sigmund Freud e Jacques Lancan. Uma interessante leitura psicanalítica da poesia de Augusto dos Anjos pode ser encontrada na obra: Chico Viana, 2012.

Cad. Nietzsche, Guarulhos/Porto Seguro, v.40, n.3, p. 215-239, setembro/dezembro, 2019. | 235 
investigativo do filósofo Nietzsche, representando, parodisticamente, o percurso investigativo (do macro ao micro, do alto ao ínfimo, de cima a baixo) do próprio Eu lírico ao longo de sua deambulação decompositória e que constrói um novo conhecimento (poético) que se vale da investigação científica para traí-la (Nietzsche também trai a ciência com a poesia, em A gaia ciência). Quão irônica, quão parodística é a crítica de Augusto a Nietzsche: acusá-lo de executar um raciocínio (que o leva à tragédia da própria loucura) quando ele mesmo - o Eu lírico - o executa fielmente ao longo de toda a sua obra. No centro do poema, temos o epicentro do movimento que inscreve a obra Eu: brincando de máscaras, o poeta ataca o filósofo, como quem ri de si mesmo diante do espelho. Fantasiado na persona de Nietzsche, o eu se esconde e se mostra sob outras personas: ele é o verme (no vocábulo "lesma") e é o próprio eu-Augusto, revelado em seu sobrenome (Augusto de Carvalho Rodrigues dos Anjos).

Obviamente Augusto também trai o filósofo, ainda que se alimente da filosofia do trágico, proposta pelo alemão, porque o cristianismo assume valor muito diferente no pensamento de ambos os autores. É o que encontramos na conclusão desse soneto. Em Eu, o Cristo é substância carbônica redentora, é verme metamorfoseado; o Cristo em Eu não é metafísico, mas substância físico-química; não é abstração celestial, mas manifestação da força telúrica que decompõe - e, por isso, em seguida recompõe - uma outra humanidade. Para Augusto, e aqui parodiando Nietzsche, o Cristo-Verme é a ponte ${ }^{35}$ bioquímica do "evolucionismo às avessas" ${ }^{36}$ que levará o último homem ao Übermensch.

\footnotetext{
35 "Grande, no homem, é ser ele uma ponte e não um objetivo: o que pode ser amado, no homem, é ele ser uma passagem e um declínio." E, em página adiante: "Amo aquele que açoita seu deus porque ama seu deus: pois tem de perecer da ira de seu deus". In: NIETZSCHE, F. Assim falou Zaratustra: um livro para todos e para ninguém. São Paulo, Companhia das Letras, 2011, pp. 16 e 17, respectivamente. O sentido de "ponte" em Nietzsche (como passagem do homem ao super-homem) influencia as primeiras gerações do expressionismo alemão: daí o título de uma das principais revistas expressionistas: Die Brücke [A Ponte]. Cf. S Lages, 2002.
}

36 Paes, 2003.

236 | Cad. Nietzsche, Guarulhos/Porto Seguro, v.40, n.3, p. 215-239, setembro/dezembro, 2019. 
Métodos tão próximos e tão distintos (eis o poder da paródia). Certamente a outra humanidade que projeta Augusto dos Anjos é muito diferente do Übermensch nietzschiano, que aqui trouxemos como paródia. $\mathrm{O}$ poeta não é exatamente schopenhaueriano, nem exatamente nietzschiano, nem haeckeliano, nem parnasiano, nem simbolista, nem... nem... A força de sua poesia reside no modo como joga com o conhecimento, para construir um conhecimento poético próprio.

Quando percorremos grande parte da fortuna crítica de $E u$, comumente nos deparamos com a informação de que a filosofia de Friedrich Nietzsche foi importante alimento à poesia de Augusto dos Anjos $^{37}$. Contudo, se o diálogo entre sua poesia e outros pensadores (em especial com a filosofia de Schopenhauer) já foi bastante investigado por inúmeros autores, em nenhuma das minhas pesquisas encontrei sequer um único trabalho que se detivesse profundamente sobre a presença da filosofia nietzschiana na poesia de Augusto dos Anjos. Certamente, a presença do trágico nietzschiano na poesia de Augusto dos Anjos permite que indaguemos sobre a presença do pensamento de Nietzsche em demais obras da literatura brasileira, contemporânea (ou nem tanto) à poesia de $E u^{38}$.

37 Foot Hardman, Olívia Arruda, Carlos Burlamaqui Kopke, Fausto Cunha, Elbio Spencer e Lucia Helena são alguns dos críticos que direta ou indiretamente se referem à presença do pensamento nietzschiano na poesia de $E u$.

38 Em novembro de 2017 tive a honra de participar como palestrante de um encontro no Departamento de Filosofia da EFLCH/UNIFESP intitulado "Recepção e atualidade de Nietzsche". Ali pudemos encontrar vários trabalhos que se atentaram à recepção do pensamento nietzschiano no Brasil. Das apresentações e textos que resultaram desse encontro, destaco um trabalho - publicado em 2019 aqui no Cadernos Nietzsche - que, creio, estabelece importante diálogo com a investigação que aqui propomos, trata-se do texto de Tiago Pantuzzi, "O Allemanismo em Recife e a primeira Recepção de Nietzsche no Brasil". Cf. Tiago Lemes Pantuzzi, 2019.

Cad. Nietzsche, Guarulhos/Porto Seguro, v.40, n.3, p. 215-239, setembro/dezembro, 2019. $\mid 237$ 


\section{Dionysus' Mask: The Reception of Nietzsche by Augusto dos Anjos' Poetry}

Abstract: This article demonstrates the reception of Friedrich Nietzsche's thought by the poetry of Augusto dos Anjos (1884 - 1914), a brazilian poet who publishes his single poetic work $E u$ in 1912 . The tragic principle wherewith the poet ironically operates the masks he wears and undresses throughout his work (which works organically as a great tragic piece); the apolinean energy with which he draws the images that carry such a lacerating (and therefore dionysiac) musicality are essential strategies of Augusto dos Anjos's poetry that certainly dialog with Nietzsche's poetic philosophy.

Keywords: Augusto dos Anjos, Friedrich Nietzsche, reception, modern tragic, modern poetry, brazilian poetry.

\section{Referências}

ALCIDES, Sérgio. “Augusto dos Anjos e o mito do Eu”. In: FINAZZI-AGRÒ, Ettore et al. Travessia do Pós-Trágico. São Paulo: Unimarco, 2006.

ANJOS, Augusto dos. Eu e outras poesias. Rio de Janeiro: Bertrand Brasil, 2006,

CALIXTO, Fabiano. "Augusto dos Anjos ou apocalipsis litteris". In: ANJOS, Augusto dos. Eu. São Paulo: Hedra, 2012.

COUTINHO, Afrânio. BRAYNER, Sônia (Orgs.). Augusto dos Anjos: textos críticos. Brasília: Ministério da Educação e Cultura, Instituto Nacional do Livro, 1973.

GIACÓIA JÚNIOR, Oswaldo. Nietzsche. São Paulo: Publifolha, 2000 (coleção Folha Explica).

HELENA, L. A cosmo-agonia de Augusto dos Anjos. Rio de Janeiro: Editora Tempo Brasileiro, 1977

KURY, Mário da Gama. Dicionário de mitologia grega e romana. Rio de Janeiro: Jorge Zahar Editora, 2003.

LAGES, Suzana Kampff. "Poesia Lírica Expressionista”. In: GUINSBURG, Jacó. O Expressionsimo. São Paulo: Perspectiva, 2002

MACHADO, Roberto. O Nascimento do Trágico: de Schiller a Nietzsche. Rio de Janeiro: Jorge Zahar Ed.,2006.

238 | Cad. Nietzsche, Guarulhos/Porto Seguro, v.40, n.3, p. 215-239, setembro/dezembro, 2019. 
Sob a máscara de Dioniso: a recepção de Nietzsche...

. Zaratustra, tragédia nietzschiana. Rio de Janeiro: Zahar, 2011.

NIETZSCHE, Friedrich. A Gaia Ciência. São Paulo, Tradução, notas e Posfácio Paulo César de Souza. São Paulo, Comapnhia das Letras, 2012

Ecce homo: como alguém se tornna o que é. Tradução, notas e Posfácio

Paulo César de Souza. São Paulo, Companhia das Letras, 1995.

. O nascimento da tragédia: helenismo e pessimismo. Tradução, notas e posfácio de Jacó Guinsburg. São Paulo, Companhia das Letras: 2007.

. Assim falou Zaratustra: um livro para todos e para ninguém. São Paulo, Companhia das Letras, 2011.

PAES. José Paulo. “Augusto dos Anjos ou o evolucionismo às avessas". In: ANJOS, Augusto. Melhores Poemas Augusto dos Anjos (Seleção de José Paulo Paes) - $4^{\text {a }}$ edição - São Paulo: Global, 2003 (Melhores Poemas 19).

PANTUZZI, Tiago Lemes. "O allemanismo em Recife e a primeira recepção de Nietzsche no Brasil" In: Cadernos Nietzsche, Guarulhos/Porto Seguro, v.40, n.1, p. 160-192, janeiro/abril, 2019.

PRADO, Antonio Arnoni. "Um fantasma na noite dos vencidos". In: Trincheira palco e letras: crítica, literatura e utopia no Brasil. São Paulo: Cosac \& Naify, 2004.

ROSENFELD, Anatol. Teatro épico. São Paulo: Perspectiva, 2008.

. A Costela de Prata de Augusto dos Anjos" In: ANJOS, Augusto dos. Obra Completa (Organnização, fixação e notas por Alexei Bueno). Rio de Janeiro: Editora Nova Aguilar, 2004, pp. 186 - 190.

SOARES, O. "Elogio de Augusto dos Anjos". In: ANJOS, Augusto dos. Eu e Outras Poesias. Rio de Janeiro: Bertrand Brasil, 2006.

VIANA, Chico: $O$ evangelho da podridão: culpa e melancolia em Augusto dos Anjos. Cf.: VIANA, Chico. O evangelho da podridão: culpa e melancolia em Augusto dos Anjos. João Pessoa: [s.n.]. 2012.

Recebido em 12/10/2019

Aceito em 20/11/2019

Cad. Nietzsche, Guarulhos/Porto Seguro, v.40, n.3, p. 215-239, setembro/dezembro, 2019. $\mid 239$ 